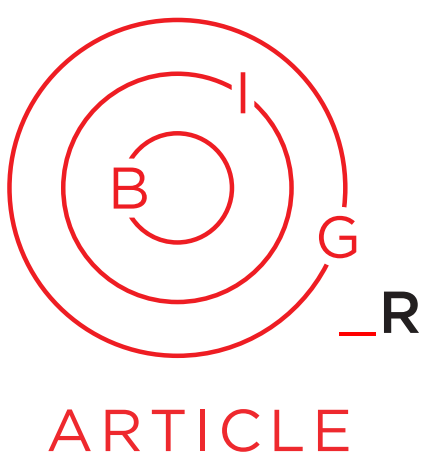

Borders in Globalization Review

Volume 1, Issue 1 (Fall 2019): 7-21

https://doi.org/10.18357/bigr11201919243

\title{
Writings on the Wall: Textual Traces of Transit in the Aegean Borderscape
}

\author{
loanna Wagner Tsoni * \\ and Anja K. Franck **
}

\begin{abstract}
The Greek island of Lesvos has a centuries-old history as a site of departure, arrival, coexistence and resistance for the forcibly displaced. This migratory chronology, however, was overwritten by the unprecedented attention that Lesvos attracted during the 2015 'refugee crisis'. This paper examines vernacular aspects of bordering, specifically the practice of border crossers and other groups standing in solidarity with-or against-them, to inscribe messages on walls in and around carceral and public spaces, viewed as a process of constructing and contesting borders from below. Closely reading numerous inscriptions collected around Lesvos reveals how borders are constructed, enacted and contested from below through borderlanders' discursive practices on some of the very walls that constitute the EU frontier's material infrastructure. This study aims to advance understandings of the historical continuity of the Aegean borderscape as a complex landscape of border effects and affects that exceed borders' legal, infrastructural and political dimensions, while also highlighting the persistence and importance of personal agency, self-authorship and identity reclamation by border populations even in the direst of circumstances.
\end{abstract}

\section{Introduction}

Between 2015-2016 more than 1.3 million refugees and migrants crossed the Mediterranean Sea in search of safety and opportunity in Europe (IOM 2015, 2016). The vast majority came through Greece, and the Eastern Aegean islands of Lesvos, Kos, Chios and Samos (UNHCR 2016a, 2016b). Although pathways of irregular migration into Europe have periodically shifted between the sea and land borders of Greece (Bernardie-Tahir \& Schmoll, 2014), the number of maritime arrivals has steadily increased since the early 2000 s.

The vast increase in refugee arrivals through Greece's sea borders during 2015 and 2016 put Lesvos 'on the global map of the great disaster sites of the 21st century' (Papataxiarchis 2016, p. 9) particularly given the island's relatively small size and population. ${ }^{1}$ While these developments attracted unprecedented, although short-lived, global attention to the perilous refugee journeys to Europe (Giannakopoulos 2016), they also obfuscated the Aegean islands' centuries-old history as well-established sites of departure, arrival, co-existence, and resistance for the forcibly displaced (Giannuli 1995; Tsimouris 2001; Karachristos 2006; Hirschon 2007; Myrivili 2009). Textual traces across Lesvos, however, tell a different story, speaking to contemporary border policies through the lived experiences of people who have confronted them through the years. It is to those texts and symbols-

\footnotetext{
* Ioanna Wagner Tsoni is a Ph.D. candidate in International Migration and Ethnic Relations at the Department of Global Political Studies at Malmö University: ioanna.tsoni@mau.se

** Anja K. Franck holds a PhD in economic geography and currently works as a senior lecturer in the School of Global Studies, University of Gothenburg: anja.franck@globalstudies.gu.se
} 
carceral inscriptions and urban graffiti-that we turn to in this paper. Inmate writings from the interior walls of the now defunct detention center of Pagani are brought into conversation with border-related graffiti from the streets of Lesvos' capital, Mytiléne, and with writings from the barbwire-lined walls surrounding the First Reception Center, and EU Hotspot of Moria. The iconography and wording of these 'writings on the wall' narrate loss and survival, reclaim lost lives and identities, while rendering countless testimonies of passage and peril at the borders visible and legible.

This paper argues for the empirical and conceptual importance of collecting, studying and interpreting art and graffiti in studying borders diachronically. In doing this, it offers a conceptual framework for interpreting the borderscape of Lesvos through the practice of graffiti writing by 'borderlanders'. The term 'borderlanders is hereafter not used as an umbrella term that indiscriminately lumps together discrete populations and persons, but as a descriptive term denoting the people that are, or have been present, within specific critical border sites. Those are people who, for whatever reason, happen to inhabit, transit through or operate within such border spaces, synchronously or at different times, under many capacities (encompassing not only migrants and refugees, but also activists, locals, and others alike). In this research, these borderlanders are brought together by their choice to leave textual markings in public spaces as testimonies of their experiences of, and perspectives on, borders, which reflect the struggles over the meaning of borders, as perceived by the various groups that are affected by them.

As a critical location of migration and border enforcement, Lesvos has played a significant role in the construction of official and vernacular imaginaries of contemporary borders as humanitarian/ securitized spaces. While official narratives around borders attempt to moderate and mediate their day-to-day effects, the writings retrieved from walls around the island relay diverse, locally-derived accounts of borders' meaning and impact on people's lives. By focussing on borderlanders' inscriptions, this study emphasizes their role as unbidden authors of the border's memory and history from below.

The article proceeds in four parts: Firstly, the analytical framework is outlined, drawing on critical border studies and borderscapes, and on graffiti scholarship. The concept of border graffiti is then elaborated, with special attention to its usage and meaning in the Greek 'crisis' context. Data collection and analysis are then detailed, followed by a problematisation of the inscriptions' linguistic and cultural translation. The affective geographies along the Greek-Turkish border are then laid out, along with the empirical material's presentation and analysis according to the five themes identified in our data. The concluding section focusses on the experiential topography of the Aegean borderscape, highlighting border graffiti's importance in challenging hegemonic discourses on borders and migration and communicating how the highly securitized border landscape of the Aegean Sea has been being experienced, confronted and negotiated diachronically from below.

\section{Analytical Framework}

Critical border scholars have shown how borders cannot merely be understood as fixed territorial lines of separation at the edge of the nation-state (Balibar 1998), but rather as a 'complex choreography of border lines in multiple lived places' (Gielis \& van Houtum 2012, p. 797). Borders do not 'simply exist', but are rather 'performed into being through a range of practices and 'rituals' (Parker \& Vaughan-Williams 2012, p. 729). Read through these practices, borders derive their meaning from social interactions and become recognizable through struggles over belonging and non-belonging (Rajaram \& Grundy-Warr 2007a, pp. xxvii-xxix). To capture these struggles, we employ the notion of the borderscape, which embraces a 'mobile, perspectival, and relational' study of borders (ibid., p. $x$ ), and draw on recent borderscape conceptualisations, which incorporate performative, participatory and senseable dimensions of borders (Brambilla 2014; Brambilla et al. 2015).

Such an approach thus grounds the abstract notions of borders and borderscapes on specific practices (i.e. top-to-bottom ones, such as surveillance and controls as well as bottom up insurgent ones, such as trespassing and rescuing), materialities (i.e. fences, walls and documents) and affects (i.e. fear, hope, indignation), and renders perceptible diverse situated experiences, negotiations and representations of/at territorial borders by different actors. The importance of a multiperspectival approach to border studies is thus underlined. This entails 'studying borders differently' and 'acknowledging the alternative boundary narratives' (Rumford 2012 p. 889), thereby foregrounding the importance of the visible and invisible work of those that inhabit border spaces. This plurilocal and plurivocal borderwork (Mignolo 1995, p. 15) is undertaken locally by 'multiple actors in this geo -politico -cultural space' (Perera 2007, p. 206), turning the Aegean borderscape, with Lesvos at its epicentre, into 'a landscape of competing meanings' (Rajaram \& Grundy-Warr 2007b, p. xv) and contrasting affects between the various groups that cross or inhabit it. Attentiveness to borders' and state's affective composition 
and geography (Laszczkowski \& Reeves 2015; Navaro-Yashin 2012; Reeves 2011) gives rise to the notion of affective borderscapes, within which the top-down bordering processes, as well as their bottom-up contestation are exerted not only practically but also affectively, and can be tracked through their human and material traces in space.

Upon the territory of Lesvos, marked deeply by shifting patterns of human migrations and the changing discourses and practices around them, the microgeographies of migrant arrival, incarceration and inhabitation are being continuously reinscribed. Among other public discursive terrains, the island's walls offer ample space for unmediated, interactive expression on borders in the form of graffiti. The inscribed messages reveal the clash or correlation of experiences, perceptions and interpretations of global bordering processes, and their local effects on individuals.

Graffiti, in its broadest sense, is the practice of unauthorized mark-making in the form of written expressions and drawings, which are scribbled, etched or painted on various surfaces, often anonymously or pseudonymously, usually within public view. It is a complex and inherently spatial practice whose exact delimitation remains problematic due to the multiple definitions and typological categorizations attributed to it (Brighenti 2010). General perceptions of graffiti range from unauthorized artistic expression, at best, to a public order violation and an act of transgression, at worst. Graffiti has also been described as an unobtrusive indicator of values and attitudes not just at a personal but also at a social level (Stocker at al. 2009), especially with regard to beliefs and sentiments that lie outside the margins of acceptable norms of ordinary social life (Gonos, Mulkern, \& Poushinsky 1976). It is a liminal practice not only socially, but also spatially, as it mostly occurs in transitional areas where social boundaries are blurred and normal rules of conduct and role expectations are held in abeyance or even in opposition' (Blake, 1981 p. 95). As a liminal practice, this transgressive and ritualized communicative process is suspended 'betwixt and between': it is situated between visual and verbal expression, pictorial and textual inscription, anonymity and identity reclamation, artistic expression and defacing.

Graffiti has been widely studied within anthropology, linguistics, arts, history, archaeology, criminology, psychology, gender studies, sociology and urban geography, among other disciplines (Bloch 2012; Burnham 2010; Dax 2015; Frederick 2009; Giles \& Giles 2010; Klingman, Shalev, \& Pearlman 2000; Lachmann 1988; Leong 2016; Otta et al. 1996; Philipps 2015). Within the field of border and migration studies graffiti has been approached from perspectives that emphasize its significance as an aesthetic and artistic expression around/about borders (Al-Mousawi 2015; Alvarez 2008). However, it still remains largely under-researched regarding its content and semiotics. A few notable exceptions refer to inscriptions of border-crossing migrants in highway box culverts across the US-Mexico border (Soto 2016); border graffiti as a contestation of national border policies and an attempt at recapturing an alternative sense of belonging (Madsen 2015); the feelings and experiences of intercepted migrants as revealed through the messages left on the walls of a Belgian police station (Derluyn et al. 2014); and tagging made by immobilized stateless people on the West Bank wall (Fieni 2016).

In the Greek context, urban public spaces have had central role in the manifestation of social struggles and the expression of popular discordance. The country's turbulent political past dating back to the period of the rise of the military junta of 1967-1974 and its fall (Metapolitefsi) ${ }^{2}$, and the toleration with which such unauthorised public writing has generally been dealt with by the authorities and citizens alike have been conducive to the pervasiveness of the phenomenon. These longstanding practices of public expressions of discordance have commonly taken place through politicized street art and slogan writing, which have utilized urban landscapes to engage publics in dialogues about contemporary social conditions (Avramidis 2012; Tsilimpounidi 2015; Tsilimpounidi \& Walsh 2010). In recent years, the corrosive effects of the enduring financial crisis, paired with the increasing influx of migrants and refugees, have reinforced sociopolitical discontent and have entrenched a sense of pervasive social injustice. Human rights' encroachment, intensification of socioeconomic precariousness and marginalization are conditions nowadays experienced not just by migrant populations, but by large segments of the violently reshuffled Greek society as well.

The magnitude and pervasiveness of contemporary social discontent has gradually extended the writing of political graffiti, as a form of non-mediated communication, beyond large Greek urban centers, such as Athens. In towns all over Greece, such as Lesvos' capital Mytiléne, the formerly kempt, whitewashed walls are nowadays saturated with graffiti, stencils, posters and stickers, and the palimpsest of narratives produced by the social realities and struggles in Greece, and beyond, as it has also been documented in previous research (i.e. Karathanasis and Kapsali 2018).

The concept of border graffiti in our work encompasses textual and pictorial communication related to border experiences and practices occurring in spaces related with, but not necessarily in, close proximity to territorial state borders. Such border graffiti is created by various actors who occupy, 
Borders in Globalization Review | Volume 1 | Issue 1 | Fall 2019

Wagner Tsoni \& Franck, "Writings on the Wall: Textual Traces of Transit in the Aegean Borderscape"

pass through and experience borderland space from contrasting positions. Border graffiti thus provides an ephemeral roadmap to navigate of borders' multiplicity and the juxtaposed meanings invested in them by different people (Sohn 2016). Messages often seem to be inscribed by any available means on any accessible surface, sometimes upon the very walls that comprise the infrastructure anchoring political borders in space. As walls become dialogic interfaces between borderlanders and other audiences, border graffiti (re)writes the frontier's narrative: it inscribes personhood, sketches perceptions, and intertwines experiences and memories from one's past and present, while carving out a sense of emplacement or dissociation in the midst of securitized spaces of existential erasure.

Similarly to other forms of public writing, we suggest that border graffiti can be seen as a medium for individuals and groups to challenge authority and contest existing policies (Moreau \& Alderman 2011) as well as a way of exercising agency, self-determination and reclaiming one's identity in the context of sociospatial exclusion (Bruno \& Wilson 2002), while being used as a means to cope with trauma (Klingman et al. 2000), or a testimony of immediate life experiences, such as concerns with one's self-identity, interpersonal relations, feelings and sentiments, clashing cultural understandings, as well as religious and political beliefs (Lucca \& Pacheco 1986).

In crisis contexts, landscapes often become direct communicative devices in themselves-their various elements turning into message boards filled with statements of reclamation and survival (Bass, 2006 p. 6). Within the enduring crisis of migration management and the protracted humanitarian disaster on the outskirts of Europe, border graffiti and the messages of hope, heed or support that they convey trace the contours of the affective geographies that the EU's (supra)national border regimes have given rise to through the years.

\section{Data Collection \& Analysis}

Our research draws upon a large collection of nearly 1000 images of graffiti photographed by the authors over several visits to three locations on Lesvos island. During our analysis, this dataset was consolidated into a collection of approximately 300 paradigmatic and highly illustrative images, a smaller selection of which is presented in this paper. The first set of photographs from the defunct (since 2009) Reception Facility of Pagani was collected in summer of 2012. Pagani is a one-story building with a small courtyard, located in the industrial area about $3 \mathrm{~km}$ northwest of Mytiléne town. No migrant reception facilities existed on Lesvos prior to Pagani's opening. Before its commissioning to house detained 'illegal entrants' between 20042009, Pagani's premises stored animal fodder and were, therefore, unsuitable for human habitation. Pagani inmates (up to 1200 at a time) were confined indoors $24 / 7$ in five overcrowded halls separated by makeshift plywood walls, with insufficient ventilation and hygienic facilities, and little to no privacy or personal space at all times. The quality of migrant reception ranged from severely deficient to inhumane throughout the facility's operation (Alberti 2010, p. 139; Cabot \& Lenz 2012, p. 166; UNHCR 2009). Violent riots erupted in the autumn of 2009, which were preceded by the disruptions caused by the NoBorder Camp to the border's and the detention centre's function (Kasparek \& Speer 2013 , p. 261), leading to the eventual closing of Pagani.

The messages found on the rotting plywood walls in 2012 remained silent witnesses of the deplorable conditions within the detention center. Detainee inscriptions were more closely photographed in the one of the two accessible ground floor halls, and in the women's and children's section on the first floor. Photographs of inscriptions found within the third ground floor hall, which remained locked, were taken through its door and window grills, and through holes dug by detainees through the decaying wood fiberboard. To the best of our knowledge this is the only collection of inscriptions of such breadth from this location, adding to its historical and evidential importance.

The downtown area of the capital of Lesvos, Mytiléne, was the second location of graffiti inscriptions' collection over multiple fieldwork visits between 2012 and 2016. The picturesque town is the administrative capital of the island of Lesvos, and of the prefecture of North Aegean. The refugee 'crisis' has been attracting a broad range of individuals, from activists and volunteers to world-renowned artists. Alongside locals, they have left their marks on public walls, defunct telephone booths, bus stations, shop windows etc., which are inundated with various types of graffiti. This heterogeneity of authors diversifies significally the content of the border/refugee-related graffiti. Local and international activist messages are mixed with purely artistic creations, such as the murals of the monthlong 'Symbiosis Lesvos Art Festival' that took place in the summer of 2016 (Symbiosis Lesvos 2016).

The collected material is analytically fragmented not only regarding the internal taxonomies of graffiti as a communicative medium, but also concerning the differentiation of their authors' motives and the classification of their content. To address this conundrum, graffiti categorised as purely aesthetic expression is purposefully excluded from this 
analysis, and we focus was placed on predominantly textual messages discursively oriented towards border and refugee politics and affects instigated by them.

The registration center/camp of Moria, located 6.5 $\mathrm{km}$ northwest of the town of Mytiléne is the third location of graffiti collection. The premises of Moria were part of the disused military base 'Paradellis' of the Mechanized Infantry of the Hellenic National Guard and functioned as a center for First Identification of asylum seekers since 2013. Its operation proved insufficient and dysfunctional ever since arrivals started picking up in early 2015: throngs of asylum seekers squatted the nearby olive groves awaiting their registration. On October 16th, 2016 an EU 'hotspot' was inaugurated within the premises of Moria amidst the steep increase of asylum seekers (up to 5-10.000 arrivals daily). On the same day, Andrea Rigoni, Italian MP and rapporteur of the Migration Committee of the Parliamentary Assembly of the Council of Europe (PACE) gave a new dimension to EU borders and their functional logic upon inspecting the facilities of Moria with his statement: 'Our impression is that this is Europe's new frontier - in this center. Outside this center, we are outside Europe' (Amna.gr 2015).

Soon after the EU-Turkey Statement on the return of inadmissible asylum seekers to Turkey was implemented on the 18th of March 2016, the remaining asylum seekers' settlements in the adjacent fields were violently cleared out and Moria became a closed registration center overnight. The living conditions of asylum seekers, however, have remained extremely challenging throughout Moria's operation to this day (Rozakou, 2017a p. 40). Several NGOs, such as Human Rights Watch, have reported how the 'lack of police protection, overcrowding, and unsanitary conditions create[s] an atmosphere of chaos and insecurity in Greece's razor wirefenced island camps' (2016, para. 2).

During our September 2016 visit, unauthorized entry to the camp was prohibited. We roamed the former settlement's scattered remnants on the nearby hillside, where traces of the olive grove squat still existed. We photographed inscriptions written with pens and markers on trees and street signs; bold spray-painted slogans on concrete walls; verses etched on moss and lichen, names carved on once wet cement. A few images of graffiti from the hotspot's inaccessible interior were also taken from the street.

Analysis began with the large photographic collection's consolidation and selection of approximately 300 illustrative items. The graffiti's deterioration due to weather exposure, wall dilapidation and other interventions often called for the photo- graphs' digital enhancement to aid readability. Minimal correction of the images' exposure, sharpness and colour were made to this end. Names and personal information have been partially redacted prior to publication to ensure anonymity. An inductive and iterative qualitative content analysis was then undertaken. Each photograph often depicted multiple instances of graffiti, written in nine identified languages and dialects (English, French, Arabic, Greek, Farsi, Pashtun, Urdu, Somalian and Sinhala). Each graffiti instance was then categorized as a separate entry and was individually reviewed based on its form (text or image), language, and location of retrieval.

Each photograph was then catalogued with a brief description of its content, its transcription, an English translation, if necessary, obtained with the help of translators, and some reflective comments based on our interpretive reading. Despite the numerous inherent epistemological and methodological issues around translation across languages, which often remain unaddressed in cross-cultural research (Temple \& Young 2004) the use of culturally-aware translators was indispensable in this research as the inscriptions' content would have otherwise been inaccessible to us.

The resulting double translation and representation of the empirical material (first by the translators from languages that the authors do not have command of, and, secondly, by the authors during the writing process) imposes additional limitations on the validity and reliability of the analysis, even more so in the absence of the messages' original authors (Twinn 1997). As explained below, however, the importance and rarity of the empirical material justified our analytical approach, and our eventual decision to consult translators.

Wishing to remain faithful to the linguistic and cultural content of the graffiti, we initially consulted native speakers of the inscriptions' languages, some of whom had been previously detained in Pagani or Moria, sourced through our personal contacts. Translators provided textual and, occasionally, cultural interpretation of the writings, which occurred during informal conversations. They were shown high-resolution photographs of the border graffiti and were asked to identify any texts they recognised, translate them into English, and briefly reflect on them if they wished to. In this way we attempted a 'crossing [of] research borders' and engaged interpreters, often with asylum-seeking background, as research collaborators (Hennink 2008, pp. 30-32; Temple \& Edwards 2002). Their responses and interpretations were later verified with the help of independent, academically-affiliated native speakers. 
The most prominent themes emerging from border graffiti's analysis were: identity and agency (re) clamation and inscription in a state of liminal waiting, encouraging and advising others in similar position, coping with border-induced embodiment and affects, and resisting border politics. These interrelated tropes appeared persistently to varying degrees, despite the spatial and temporal variation of this research across three fieldwork locations and over many years.

This type of research poses numerous limitations. Firstly, images for this study cannot possibly reflect the entire range of expression of borderlanders in Lesvos: open-ended as graffiti writing might be, it is still a selective practice, allowing expression only to those possessing the means and ability to articulate their thoughts in writing. Moreover, the selectivity of this process is exacerbated through the serendipitous process of the inscriptions' discovery. Conclusions cannot be considered authoritative, either, as all information available to us was imparted through the inscriptions in the absence of their authors. The disambiguating of motives, affects, thoughts and meanings is particularly difficult after-the-fact and necessarily based on assumptions. Every effort was made from the authors', however, to remain true to their meaning, including focussed discussions with former Pagani detainees and the assistant translators to contextualize and comprehend the graffiti's form and content.

\section{Writing Affective Geographies on the European Border Wall}

\section{Inscribing and reclaiming identity in liminal waiting}

A striking observation made while studying the photos from Pagani was its walls' inundation with inscriptions. Texts of varying sizes mottled every writable surface: from sprawling Persian calligraphy in intricate patterns and block letters in moisture-blotted red marker, to hidden ball-point pen scribbles and faint pencil jots. Like a towering diary of passage, the makeshift detention centre's high walls formed a message board of survival, overflowing with testimonies of people locked into transit.

Migration and refugee passage are liminal states, often forcing people into sociospatial limbo for extended and externally-set time periods, while the outcome of their waiting (release, deportation or the extension of detention) remains unpredictable (Boer 2015; Noussia \& Lyons 2009; Papoutsi, Painter, Papada, \& Vradis 2018). Deceleration or total arrest of migrants' journeys are, thus, not mere side effects of this process, but different means of states' 'frontier praxis' in themselves. The active usurpation of irregular migrants' time by the authorities reveals the complex economics of illegality, which go hand in hand with the existing biopolitical dimensions of Europe's border management (Andersson 2014a, p. 795). Temporality is, therefore, a crucial parameter of the ways migration experiences are organized where experiences of waiting are, as Conlon (2011, p.353) argues, both 'imbued with geopolitics' as well as 'actively encountered, incorporated and resisted' throughout the spaces that migrants and refugees inhabit. Pagani graffiti indicates the centrality of time-keeping in detained migrants' life, through their individualised methods of tracking the duration of their imprisonment (Figure 1). Most commonly, timespans were marked textually by writing one's date of arrival (to Greece/Lesvos) or the date of their imprisonment, and their predicted day of eventual release, or 'liberation' (Figure 1c). Some marked days with rows of lines or crosses (Figures 1b, 1e), while others used pictographic methods of timekeeping. The calendars' format indicates that the detention period's anticipated duration (around 30 days) was often known to the migrants in advance. Subsequently, they drew countdown matrices of fixed duration, such as columns or rows of outlined circles, which were later filled in as days passed (Figure 1d). This time-keeping method indicates an attempt to reinstate a sense of predictability in the migrants' uncertain temporality of passage, while maintaining a future-oriented perception of time and an impression of onward progression of their journey. Differences in the recorded length of imprisonment indicate the prevalent arbitrariness of living and administrative conditions faced by migrants, of which detention is but one.

Unlike the anonymity that customarily characterizes graffiti messages, Pagani detainees strived to retain their eponymity (Figure 2). People's names and detailed biographical information were shared on the walls - often down to their town and neighbour-

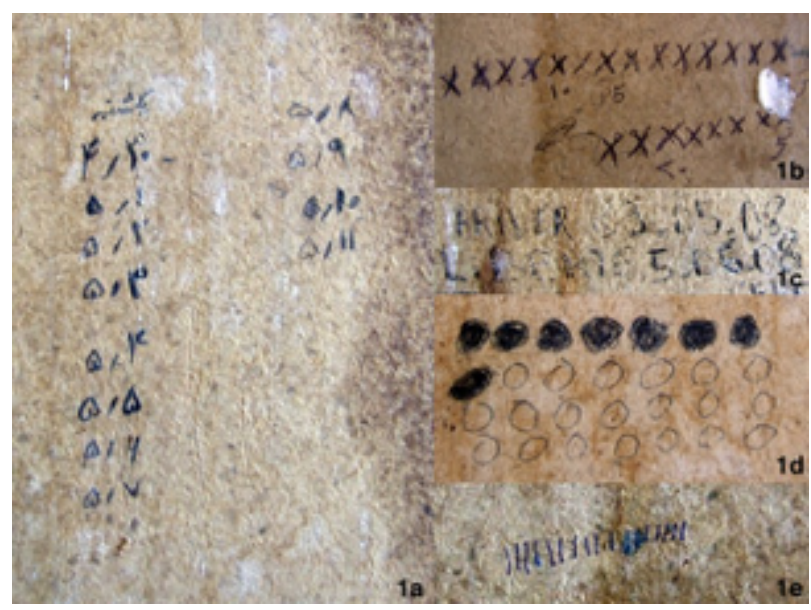

Figure 1: Tracking time in detention (Pagani 2012). Photos by loanna Wagner Tsoni. 


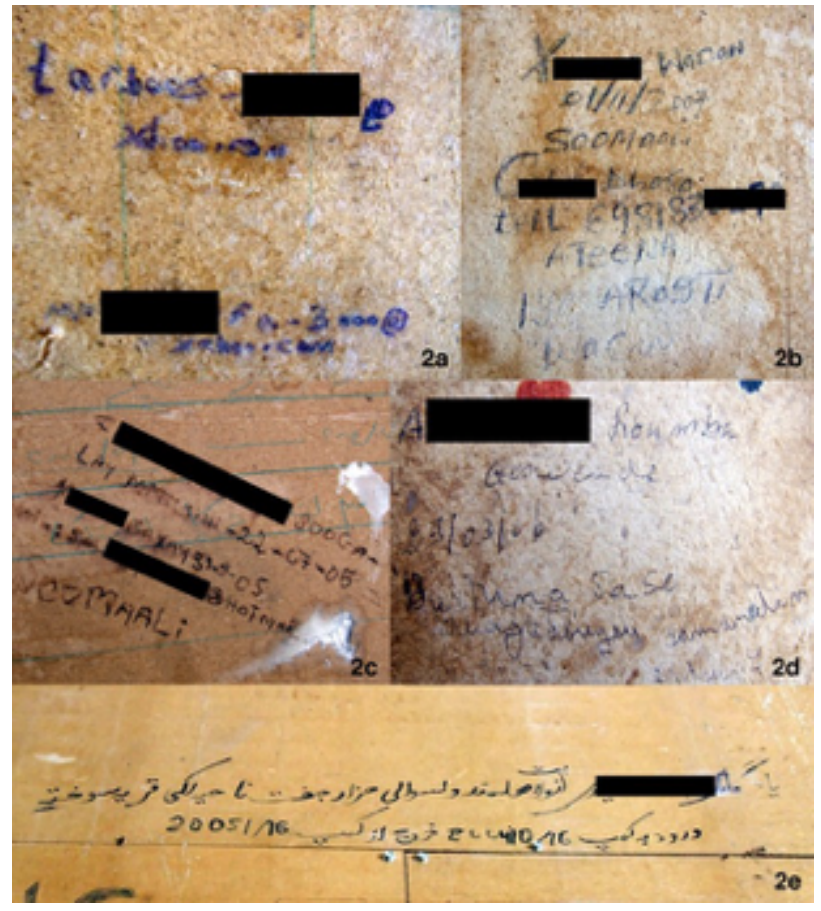

Figure 2: Inscriptions of personal biographical and contact information (Pagani 2012) Photos by loanna Wagner Tsoni.

2a: tarboes_XXX@yahoo.com; XXX_3000@yahoo. com.

2b: X. Wacan / 01/11/2007 / Soomaali / C. Dhako / Tell 698183 XXX/ Ateen (Athens).

2c: C. Sooga / Lay Mytilini-22-07-05 / K. Baxay 31-8-05 / Email: SaXXX@hotmail / Soomaali.

2d: A. Rouamba / Geswende / 29/03/06 / Burkina Faso / Ouagadougou / Samandin / Secteur 7.

2e: Memento of A. Haidari from Helmand Province, district of Hazar Jooft Laki sector village Qaria Sokhta / entry to the camp 16/10/2004 exit from the camp 16/01/2005.

hood of origin (Figures 2d, 2e), email addresses and phone numbers (Figures 2a, 2b, 2c), as well as nicknames and different self-ascribed identity markers (e.g., 'Ghetto Boss', 'Djolof 4 Life' - not pictured here).

The practice of sharing such personal and potentially compromising information publicly stands in direct opposition to the essence of the correctional spaces where they were found, where migrants would often conceal or falsify their personal details deliberately to obtain paperwork with more favourable information in the hope of further supporting their future asylum claims (Derluyn et al. 2014, p.7). In this case walls featured as message boards of emergency communication where one could mark themselves as 'safe and well', restore lost links with family and travel companions or forge new ones, and reaffirm their personal identity.

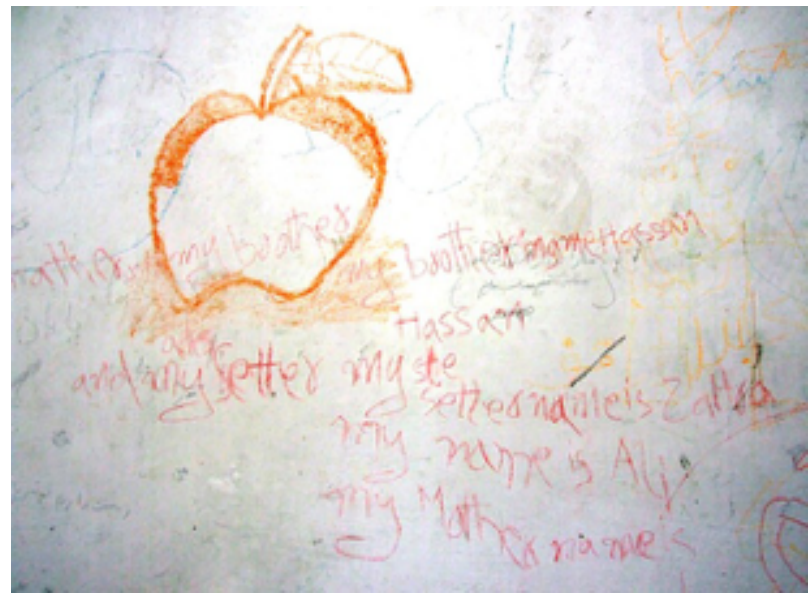

Figure 3: Ali's family introduction in English (Pagani 2012). Photo by loanna Wagner Tsoni. My father and my brother / my brother name Hassan / Hassan / ads / and my setter / my ste / setter [sister] name is Zattra / my name is Ali / my mother name is.

On the first floor, where women and minors were detained, the white walls offered the incarcerated children a minimal space for playful expression. Colourful crayon drawings of butterflies, flowers, stars and human figures were found, as well as attempts at exercising writing skills in Arabic, English and Somalian. Ali's text (Figure 3) stood out, as he used the rough plaster wall as an un-erasable whiteboard upon which he practiced spelling his family's names, a testimony to the precedents for the persistent legal and policy practices around the often unlawful confinement of un/accompanied minors, and their separation from other family members. In sum, we perceive the graffiti found in Pagani as expressing the detainees' claim for a particular type of place- and time-based recognition and re-definition of their identity within the socio-spatial limbo experienced in the centre.

Contrary to the inscriptions in Pagani, graffiti found around Mytiléne and Moria did not contain migrants' personal information. The only exception was a collection of stencils in Greek (Figure 4) identifying three migrants who had died between 2014 and 2015 in the Amygdaleza detention center near Athens (Morfis 2015). Probably spray-painted by local activists in an alleyway near the Mytiléne port, these stencils indicate how struggles against border-induced violence suffered by migrants span across Greece, while commemorating the dead and bringing awareness to the conditions of their, largely unreported, deaths.

\section{Encouraging and advising others}

Another central trope commonly observed in many messages inside Pagani was the detainees' expres- 
Borders in Globalization Review | Volume 1 | Issue 1 | Fall 2019

Wagner Tsoni \& Franck, "Writings on the Wall: Textual Traces of Transit in the Aegean Borderscape"

sion of solidarity to other intercepted migrants, as well as offering advice, encouragement and wishing success to those coming after them. Gestures and expressions of camaraderie can alleviate the spatial and social isolation experienced by detainees and help the construction of a discretional communal identity around their life stage they share at the time.

Courageousness is one of the main themes expressed in such messages and is often presented as a prerequisite for earning one's freedom (Figure

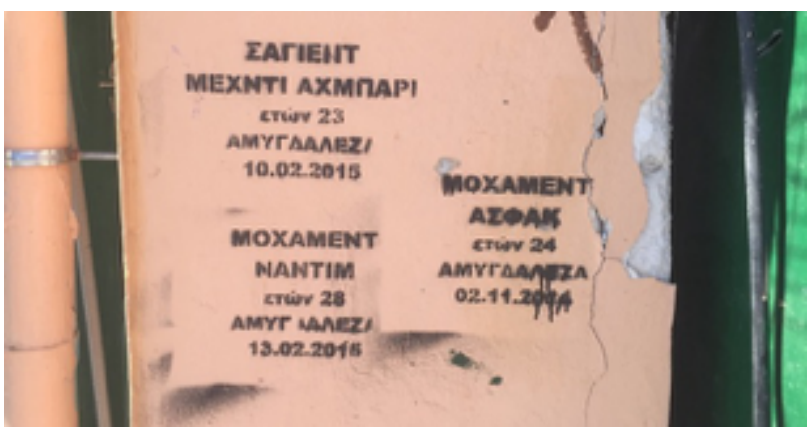

Figure 4: Stencils commemorating the deaths of three migrants imprisoned at the Amygdaleza detention center (Mytiléne 2016). Photo by loanna Wagner Tsoni. Sayed Mehdi Ahbari / 23 years old / Amygdaleza / 10.02.2015; Mohamed Asfak / 24 years old / Amygdaleza / 02.11.2014

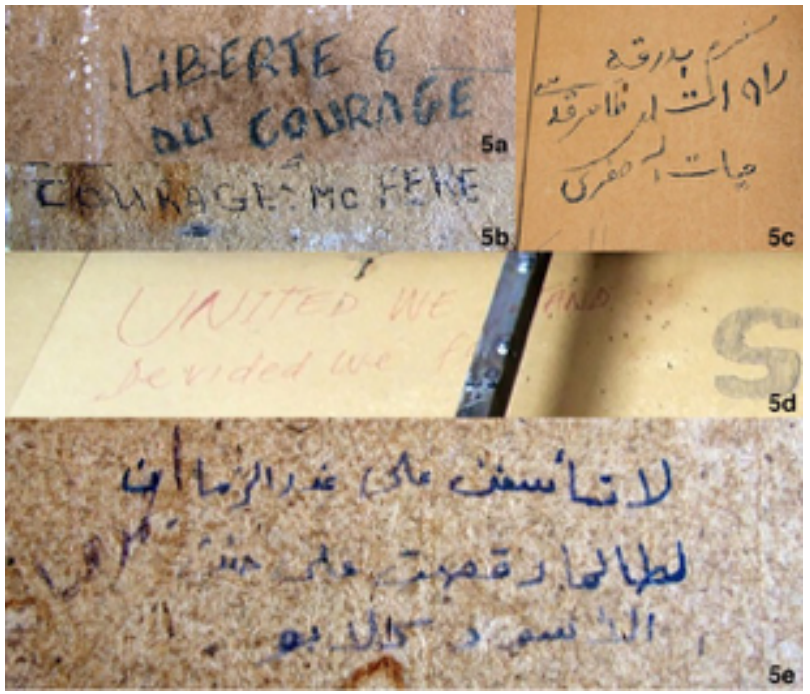

Figure 5: Messages of brotherhood and encouragement (Pagani 2012) Photos by loanna Wagner Tsoni.

5a: Liberty, courage.

$5 \mathrm{~b}$ : Courage my brother.

5c: You might get lost in the desert but you should never enter this camp [Detention in Pagani is worse than being lost in the desert].

5d: United we stand, divided we fall.

5e: Do not lament the treachery of time; long have dogs danced over the carcasses of lions [Do not be sorry about life's bad turns]. 5a), along with the importance of resilience and fearlessness despite danger's or death's imminence (Figure 6d). Total strangers are warmly saluted as 'brothers' (Figure 5b), implying links of affinity growing between people affected by similar hardships. The significance of supporting each other and fostering unity and collaboration in the face of adversity is highlighted (Figure $5 d$ ), lest misfortune and defeat would come upon them. The advice to avoid detention in Pagani at all costs as it is worse than being lost in the desert is offered elsewhere, warning unsuspecting newcomers for what is to come (Figure 5c).

An excerpt from old Arabic poem of disputed authorship (Wikisource.org 2017) found inside Pagani (Figure 5e) highlights the significance of maintaining one's dignity and pride, and not resorting to self-pity and despair despite the degree of betrayal from one's given life circumstances. 'Pride is of great importance for an Arab and land is so as well. To be uprooted and then imprisoned by a foreigner (a westerner) is a great insult. It calls for self-pity and for pain. The lion is the prisoner, the migrant, the refugee, the undocumented and unwelcomed. The dog is the prison guard, the authority, etcetera.' (Salim, 27 years old, Syria, translator from Arabic). Despite their fatalism, the verses carry an implicit consolation to their imprisoned readers: 'Do not feel sorry because this is how life usually goes. Although defeated for now, you remain superior to your captors'.

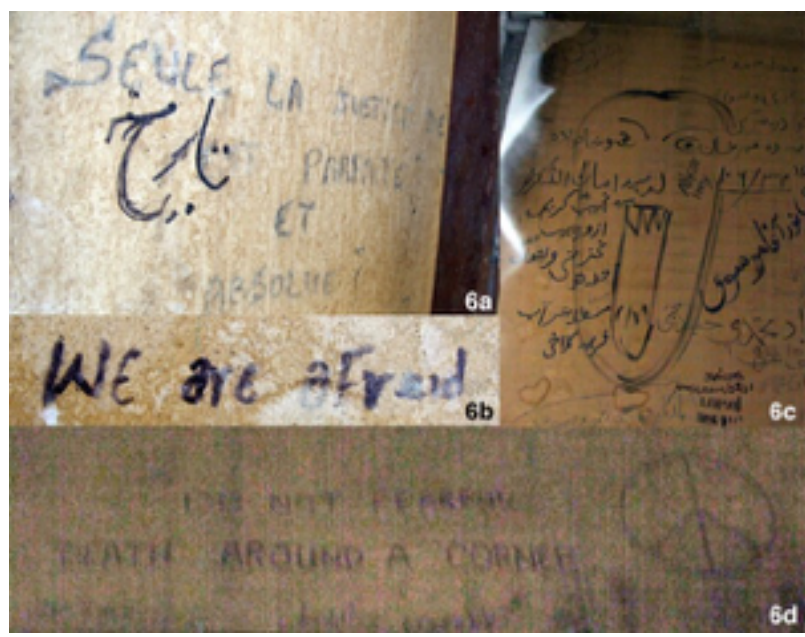

Figure 6: Border affects while in detention (Pagani 2012) Photos by loanna Wagner Tsoni.

6a: Only god's justice is perfect and absolute (faith, hope).

6b: We are afraid (fear).

$6 \mathrm{c}$ : Drawing of frightening face (fear).

6d: Do not [be] fearful [even though] death [is] around a corner (courage, determination). 


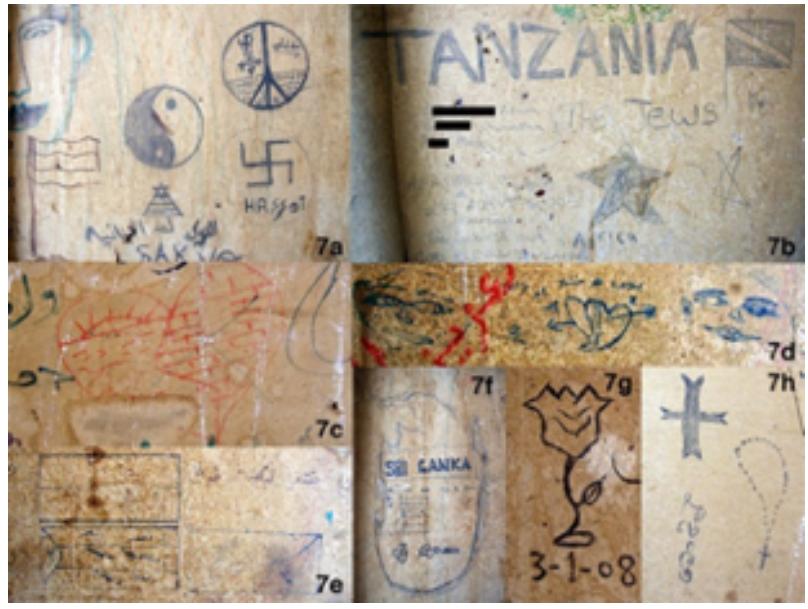

Figure 7: Symbols and signs of personal significance (Pagani 2012) Photos by loanna Wagner Tsoni.

7a: Drawings of a face; a yin-yang symbol; a swastika; an unidentified symbol resembling the peace symbol with additional details; the cedar of Lebanon with the Star of David on its top and the inscription 'The Lebanese Troops' at its bottom; the Iranian flag.

7b: Tanzania; the flag of Tanzania; pentagram star symbols with the inscription: 'S. Adam, B. Chavalha, P. Malik - The Jews. Arrival: 24 August 2005, Tanzania, The luckiest people in Africa. God bless Tanzania. Africa.

7c: Drawing of a broken heart containing a rising/ setting sun over an open landscape to the left (evoking freedom or nostalgia), and a brick wall with a small grilled window to the right (signifying captivity).

7d: Drawing of two faces and two hearts pierced by an arrow.

7e: The outlines of three flags.

7f: The outline of Sri Lanka with the inscription 'Sri Lanka, Arrived 24.8.2005, K. Fernando, Manjula, Prabath, Anuva, 17.9.05 Janaka', and the words 'Sri Lanka' in Sinhala

7g: Drawing of a rose and the date 3-1-08.

7h: Drawings of a cross and a rosary; the name Morris in Sinhala.

Messages of support and solidarity, however, are not only exchanged between migrants. Locals and activists often write in support of migrants near spaces of incarceration and other public areas, holding ground against the advent of xenophobia and claiming pockets of public space as safe for the newcomers as demonstrated below (Figures 9 and 10).

\section{Border embodiment and affect}

As it has been empirically indicated so far, bordering processes are constituted not just through their more tangible aspects, such as the legal, infrastructural and political dimensions of borders (Andersson 2014b) but also through feelings, emotions, embodied experiences and affective dispositions by a variety of

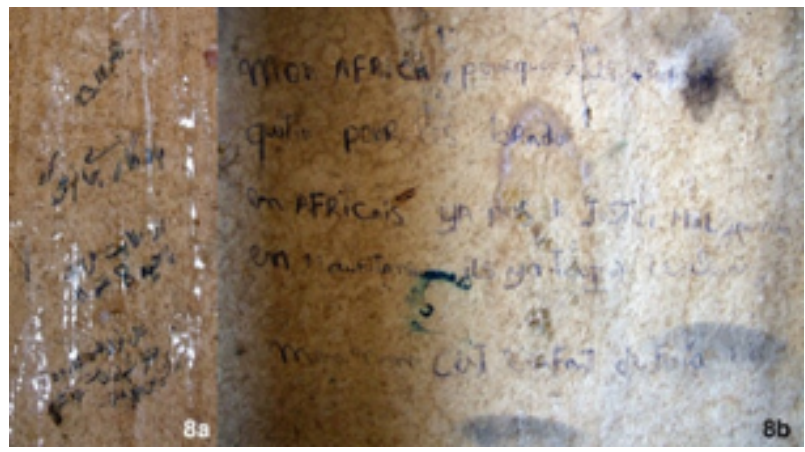

Figure 8: A journey in search of justice, safety and self-realization, and arrival experienced as rebirth (Pagani 2012). Photos by loanna Wagner Tsoni.

8a: Date of birth 20.12.2008. At the black sea 10 o clock at night in the international ship of Greece.

8b: My Africa why have you abandoned [?] for the [?]. In Africa there is no justice [?]. In Mauritania there is always danger. My name is [?] de Fufa.

actors (Navaro-Yashin 2012; Reeves 2011). By paying attention to the border-encountering bodies and their sensory and affective experiences we observe how complex emotional geographies of borders unfold in practice. Through the wall inscriptions, fragments of the visceral and affective synthesis of the borderscape are offered: vulnerability and discouragement are revealed; mental resilience and group solidarities are shaped, and encouragement is offered in an effort to maintain hope throughout the challenges of life in transit and detention. Inside Pagani, feelings of despondency, anguish and fear in the face of life-threatening dangers are expressed through writings and drawings (Figure 6). Religion plays a very important role throughout the entire migration trajectory and especially during times of distress and emotional and physical trial (Dorais 2007; Gozdziak \& Shandy 2002; Hagan \& Ebaugh 2003). Writings across Lesvos-scribbled prayers, religious symbols and invocations to God-found in Pagani, support this claim (Figure 6a, 7h).

Expressions of love, affection and longing are also widespread. People profess love for their home countries, family members or beloved ones with words or symbols (Figure 7). Others imply how their support to dissident ideologies and those who express them remains unwavering, despite being part of what forced them to flee. A Somalian detainee in Pagani, writes of his love for Hadrawi-a prominent Somali poet and songwriter who penned notable protest works ('I love Hadrawi', Pagani 2012-not pictured here). Nostalgia, homesickness and deep longing for freedom, are also expressed both in words and symbols, such as birds in flight, footsteps walking away, a broken heart with its right side made of brick wall, and a sunrise over an open field on its left (Figure 7). 


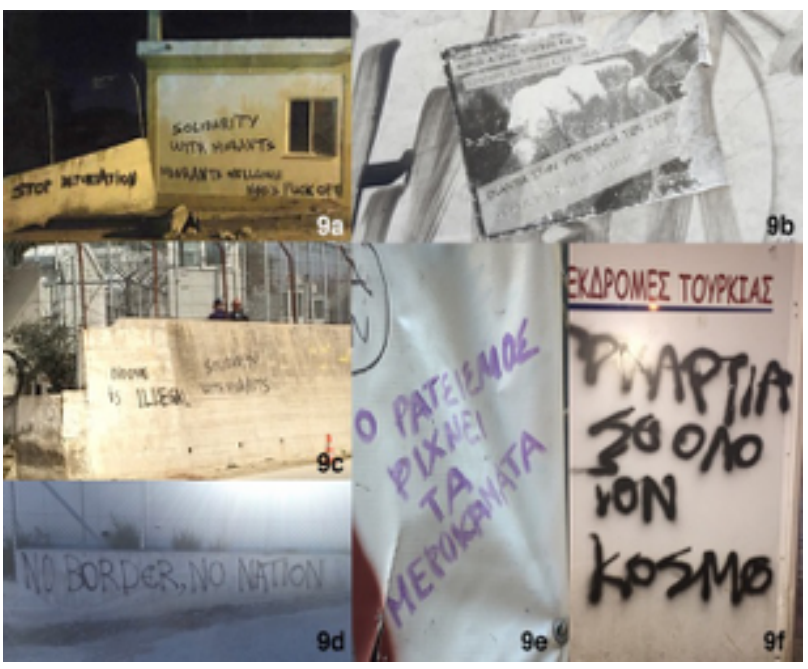

Figure 9: Resisting border politics and calling for alternative visions for border and migration management (Mytiléne and Moria, 2015 and 2016). Photos by loanna Wagner Tsoni.

9a: Stop deportation - Solidarity with migrants. Migrants Welcome. NGO's Fuck off (Moria 2015)

9b: Common struggles of locals and migrants against the devaluation of our lives (Mytiléne 2016).

9c: No one is illegal. Solidarity with migrants (Moria 2016).

9d: No border - No nation (Mytiléne \& Moria 2016). 9e: Racism makes wages drop (Mytiléne 2016).

9f: [Give] Papers to everyone (Mytiléne 2016).

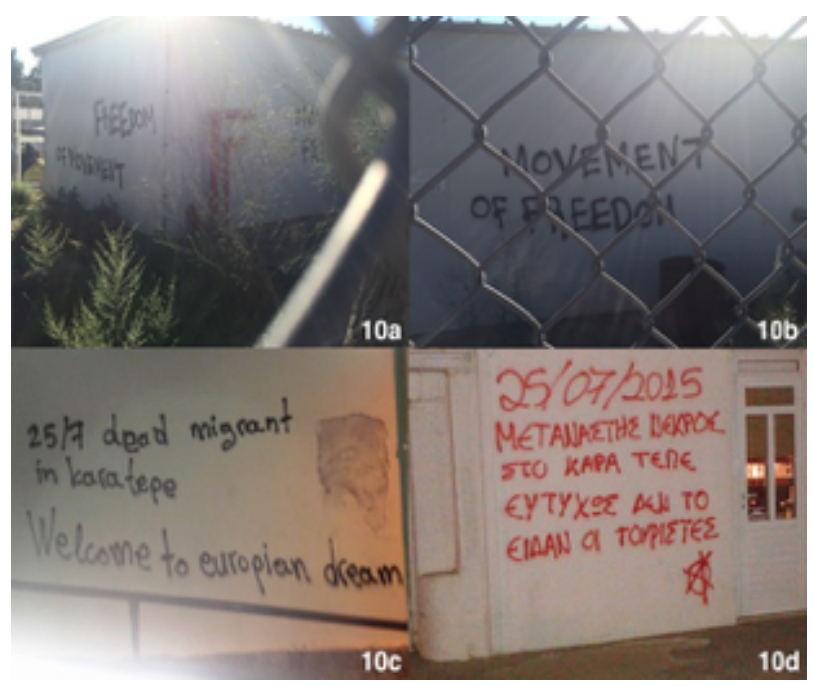

Figure 10: Calls for one's right to movement, life and dignity (Mytiléne and Moria 2016). Photos by Ioanna Wagner Tsoni.

10a: Freedom of movement (Moria 2016).

10b: Movement of freedom (Moria 2016).

10c: $25 / 7$ - Dead migrant in Kara Tepe. Welcome to European dream (Mytiléne 2015).

10d: 25/07/2015 - Dead migrant in Kara Tepe. Thankfully the tourists did not see it (Mytiléne 2015).
Complex emotional entanglements are sometimes revealed, such as feelings of betrayal and abandonment by one's country/continent of origin, which sets off the migratory journey in search of justice, safety and self-realisation (Figure $8 \mathrm{~b}$ ), while the moment of border-crossing and rescue by the coastguard is experienced as rebirth (Figure 8a). Contrary to what previous research indicates about male-designated locations (Ferris 2010; Soto, 2016; Yogan \& Johnson 2006), no textual or visual obscenities were observed in Pagani, nor insults or defacement of others' messages and/or religious symbols.

As previously discussed, political graffiti in Greece is a prevalent communicative and expressive medium and a ubiquitous part of the urban landscape (Avramidis 2012; Tsilimpounidi 2015; Tsilimpounidi \& Walsh 2010). Much like in other Greek cities, writings around Moria and Mytiléne often express political indignation and anger (Karathanasis and Kapsali 2018). The writings that this paper focuses on were directly related to migrant arrivals and the refugee crisis and used explicit language against authorities and institutions involved in the EU border regime, decrying their policies and condemning their practices (see Figures 9, 10 and 15).

\section{Resisting borders and border politics}

Most documented inscriptions from Mytiléne and Moria are politically informed slogans that contest current border policies (Figures 9 and 10). Some chastise the workings of the European Union's border regime, proclaim a different vision for immigration rights and border management and question whether certain foundational principles of both the Greek and European identity remain tenable in the light of the border and migration policy mishandlings.

Calls for borders' abolishment and the cessation of deportations are common, as is the expression of indignation towards the role of humanitarian NGOs and the 'refugee rescue industry' (Figure 9a). Many messages demand the abolition of borders, safe passage, the fair processing of asylum claims and the supplementation of documents to the newly arrived (Figures 9d and 9f). Others speak against the illegalization and criminalization of migration (Figure 9c). Some messages address widespread populist and xenophobic discourses, dismissing the purported negative effect of migration on the labour market (Figure 9e). Some inscriptions deconstruct the division between locals and migrants, indicating common struggles faced by Greeks and migrants, and the need for joint action against the compounded crises they are subjected to: the financial one, and that of refugee reception and asylum (Figure 9b). 
Calls to an ever-more restricted freedom of movement, as both a universal human right and one of the central EU policy pillars, are spray-painted on the container dwellings inside Moria (Figures 10a and 10b). Others expose the illusion that the EU is an area of safety and prosperity, debunking the myth of 'the European dream', with which the forcefully displaced are violently faced upon the continent's doorstep (Figure 10c). Scattered graffiti elsewhere comments on human rights' infringements such as one's right to life, liberty, security and equality in dignity and rights. Another alludes to the concealment efforts regarding the humanitarian crisis' magnitude on the island to safeguard the tourism industry and keep holiday-makers undisturbed (Figure 10d). Tourists' and migrants' wellbeing is valued differently, according to the graffiti, and the experiences of their differentiated bodies are worlds apart, encountering the same landscape either as a holiday resort, or a 'death camp'. Migrants and tourists on Lesvos exist on two parallel, asymptotic planes, which, as in other beachfront border zones, prohibit encounters and meaningful engagement (Al-Mousawi 2015). Criticism is expressed towards the widespread discounting of Greece's long-standing migratory and refugee history, and the erosion of philoxenia (hospitality), Greece's dominant cultural code of dealing with alterity (Rozakou 2017b), indicated in graffiti such as these: 'Our grandfathers were refugees, our parents were migrants, us racists?', Mytiléne; 'No detention can be hospitable', Mytiléne-not pictured here.

Besides political graffiti, poem verses were also encountered (e.g., 'No one leaves home unless home is the mouth of a shark, you only run for the border if the whole city is running as well', Moria 2016); proverbs on loss and longing for a homeland (e.g., 'Our only homeland is our childhood dreams', Moria 2016), and excerpts from the Quran (not pictured here). Even such instances of less personal graffiti, however, assert one's right of be/coming 'here' despite prohibitions and perils; urge migrants and activists to sustain hope in the face of adversity, and call out for solidarity with those affected by displacement and migration politics.

As Lesvos has turned into an emblematic example of the EU border regime's workings, aside from its prominent national administrative and symbolic stature, it now sets a global paradigm on practices of, and attitudes towards migration management. The messages expressed across its public spaces and at locations of critical importance-such as the Moria hotspot, the city hall, the coastguard building, the central square and the port facilities among others-indicate a microgeography of resistance and solidarity that includes border struggles across time and space, as well as across lines of gender, class, and nationality. They reassert the right of newcomers to life, dignity, safety, personhood and presence as well as free mobility.

Their content resonates with questions raised by individuals, solidary movements and researchers elsewhere in Greece and in the world, calling for a just and humane resolution to the currently untenable migrant and refugee reception system both on Lesvos and elsewhere. As such, they echo wider political movements and discourses currently at play, and have, therefore, the potential to bring about broad and lasting sociopolitical effects. On the other hand, the almost absolute monopolization of public expression by locals and activists in the island's urban space-even though migrants and refugees roam the same spaces daily-indicates the persistent relegation of migrant voices into the margins of crucial discourses concerning their lives. As a result, an inadvertent process of rebordering takes place in the current debate on border politics.

\section{Conclusion}

The spaces of migrant and refugee arrival, transit and containment are rife with inscriptions that often remain unnoticed. Whether condemning contemporary migration and asylum policies, voicing solidarity with refugee struggles, expressing one's innermost feelings while in detention, or piecing together a wavering sense of identity, this paper suggests that such border graffiti can offer important insights about the ways hegemonic discourses on migration are being experienced, negotiated and confronted from below in more (or less) obtrusive ways.

The messages inscribed by various people and groups that inhabit or cross borders trace the experiential topography of the borderscape, telling us of the myriad ways the northern Aegean maritime frontiers can be 'experienced, lived as well as reinforced and blocked but also crossed, traversed and inhabited' (Brambilla 2015, p. 17). These inscriptions often express the complexities of identity construction and social belonging within localities embedded in the epicentre of national and international border policy contexts. In doing so, the actors engaging in border graffiti open up the question of 'de-essentializing the border landscape and reframing imaginaries that cope with the growing securitization of international limits' (Dell'Agnese \& Amilhat Szary 2015, p. 9). The 'writings on the wall' that we have recorded in this paper speak directly to the ways in which borders are in many ways 'landscapes of competing meanings' (Rajaram and Grundy-Warr 2007b, p. xv). As such, these inscriptions can also be perceived as bordering practices in themselves through which the border is 'performed into being' (Parker \& Vaughan-Williams 2012 p. 729). 
Whereas our analysis has departed from a close reading of these fleeting 'writings on the wall', the application of this phrase goes beyond its literal meaning to encompass its metaphorical dimensions. As such, the inscriptions serve as bearers of portentous, yet overlooked, notations of borders' incipient essence, which lies partly in their capacity to legitimize violent, exclusionary and discriminatory practices that dehumanize irregular bordercrossers (Jones 2016). Border graffiti cues to the silenced genealogies of individual and collective frontier struggles and of the multiple transgressions transpiring within the Aegean borderscape, as told by those whom the workings of contemporary border regimes have relegated into the margins of society and discourse.

The presence of the border graffiti, much like that of the border crossers themselves, is fleeting. The messages of resilience and contestation of the current migration policies that they express, however, remain constant and congruent with border struggles in Greece and elsewhere in the world. Despite the silencing or marginalization of the voices that try to raise awareness and condemn the longstanding complicity of national and European authorities in the current bleak-if not downright outrageous-picture of refugee reception in Greece and the EU, these voices persist. They call out the systematic violations of human rights and expose the lack of basic provisions and the human suffering inside camps run by national and EU authorities.

Contrary to contemporary depictions, the border graffiti chronicled in this paper gives evidence that the smuggled migrants' presence on Lesvos had been as pervasive as it had been overlooked and deliberately unaccounted for since the late 1990s and early 2000s. Up until their recent explosive increase, the migrants' pre-sunrise arrivals and their trudging roadside convoys, their urban huddles and their squalidly incarcerated packs were an open secret among the local as well as inter/national authorities and publics. Little was said and even less was done for the remediation of the conditions they faced, similarly to what successive waves of displaced populations arriving at or departing from Lesvos' shores following centuries-old pathways experienced. In spite of the diachronic apathy to their plight, however, and the concerted efforts at effacing their traces, their inconspicuous writings offer us a counterhistory of passage today.

Despite attempts at haphazard prettifying of the physical and communicative space around refugee settings, highlighted by the rushed figurative, and quite literal, whitewashing of the reality on the ground, those unsolicited, spontaneous forms of expression still manage to seep through the surface. The wall outside Moria's old entrance, now a locked gate on a side street, bears witness to the layers of ongoing discourse around migration management and the constant whitewashing of the authorities' failure to protect and upholding refugee rights (Figure 11).

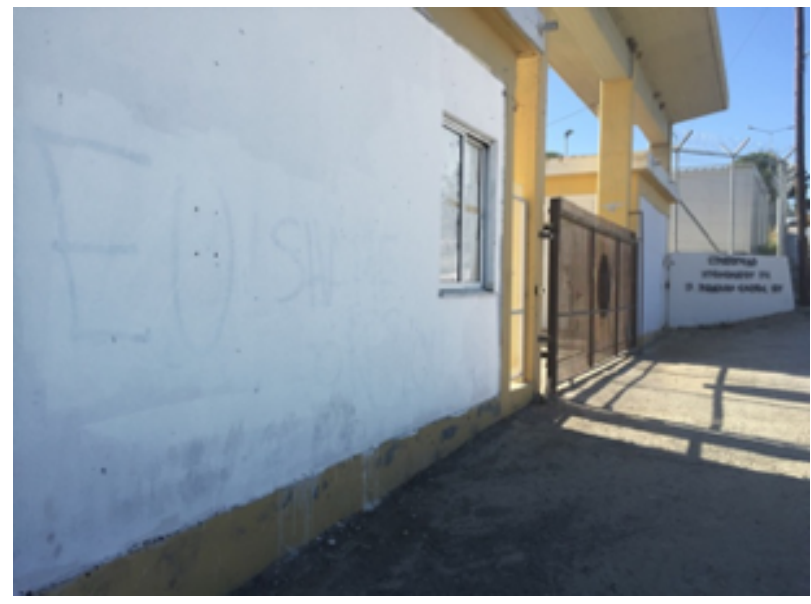

Figure 11: Whitewashing the bordering practices of the EU outside Moria (Moria 2016). 'EU shame on you' Photo by Ioanna Wagner Tsoni.

\section{Notes}

1 To grasp the magnitude of the phenomenon relative to Lesvos' geographical and population size (1,639 $\mathrm{km} 2$ and 86,500 inhabitants as per the latest National Census of 2011), according to Hellenic Coast Guard data, 502,433 unauthorised entries were officially recorded on Lesvos in 2015 alone (Rontos, Nagopoulos and Panagos, 2019).

2 Metapolitefsi (Greek, translated as "polity/regime change") marks a period in modern Greek history after the fall of the military junta of 1967-74. It is the longest period of political and social stability in the modern history of Greece and includes the transitional period from the fall of the dictatorship to the 1974 legislative elections and the democratic period immediately after these elections until the present.

\section{Works Cited}

Al-Mousawi, N. (2015) Aesthetics of migration. Street art in the Mediterranean border zones, Ibraaz, Platform 008. Available at: http://www.ibraaz.org/essays/116 (Accessed: 1 May 2019).

Alberti, G. (2010) "Across the borders of Lesvos: The gendering of migrants' detention in the Aegean," Feminist Review 94(1), pp. 138-147. https://doi. org/10.1057/fr.2009.44

Alvarez, M. (2008) "La pared que habla: A photo essay about art and graffiti at the border fence in Nogales, Sonora," Journal of the Southwest 50(3), pp. 279-304 https://www.jstor.org/stable/40170392 
Amna.gr (2015) "First refugee 'hotspot' opens in Lesvos," Athens News Agency - Macedonian Press Agency (ANA-MPA). Available at: http://www.amna.gr/english/ articleview.php?id=11676 (Accessed: 8 August 2017).

Andersson, R. (2014a). "Time and the migrant other: European border controls and the temporal economics of illegality," American Anthropologist 116(4), 795-809. https://doi.org/10.1111/aman.12148

Andersson, R. (2014b) Illegality, Inc. Clandestine migration and the business of bordering Europe. Oakland: University of California Press.

Avramidis, K. (2012) "Live your Greece in myths: Reading the crisis on Athens' walls," Professional Dreamers. 8.

Balibar, E. (1998) "The borders of Europe," in Cheah, P. and Robbins, B. (eds) Cosmopolitics: Thinking and feeling beyond the nation. Minneapolis: University of Minnesota Press.

Bass, J. (2006) "Photographic journal. Culture in nature: Reclaiming place after Katrina," FOCUS on Geography 48(4), pp. 1-8. http://doi.org/d53ctf

Bernardie-Tahir, N. and Schmoll, C. (2014) "Islands and undesirables: Introduction to the special issue on irregular migration in Southern European islands," Journal of Immigrant \& Refugee Studies 12(2), pp. 87-102. http://doi.org/ddg9

Blake, C. F. (1981) "Graffiti and racial insults: The archaeology of ethnic relations in Hawaii," in R. A. Gould and Schiffer, M. B. (eds) Modern material culture: The archaeology of us. New York: Academic Press, pp. 87-99.

Bloch, S. (2012) "The illegal face of wall space: Graffiti-murals on the Sunset Boulevard retaining walls," Radical History Review (113), pp. 111-126. http://doi.org/ddhb

Boer, R. Den (2015) "Liminal space in protracted exile: The meaning of place in Congolese refugees' narratives of home and belonging in Kampala," Journal of Refugee Studies 28(4), pp. 486-504. http://doi.org/f7372r

Brambilla, C. et al. (eds) (2015) Borderscaping: Imaginations and practices of border making. Farnham: Ashgate.

Brambilla, C. (2015) "Exploring the critical potential of the borderscapes concept," Geopolitics 20(1), pp. 14-34. http://doi.org/gc945q

Brighenti, A. M. (2010) "At the wall: Graffiti writers, urban territoriality, and the public domain," Space and Culture 13(3), pp. 315-332. http://doi.org/fmcpkc

Bruno, D. and Wilson, M. (eds) (2002) Inscribed landscapes. Marking and making place. Honolulu: University of Hawai'i Press.

Burnham, S. (2010) "The call and response of street art and the city," City 14(1), pp. 137-153. http://doi.org/dpgk3h

Cabot, H. and Lenz, R. (2012) "Borders of (in)visibility in the Greek Aegean," in Nogues-Pedregal, A. M. (ed.) Culture and society in tourism contexts. Bingley: Emerald Group Publishing Ltd., pp. 159-179.

Dax, E. M. (2015) "Ararat's J Ward - A history cast in stone," World Cultural Psychiatry Research Review 10(3/4), pp. 168-174.

Dell'Agnese, E. and Amilhat Szary, A.-L. (2015) "Borderscapes: From border landscapes to border aesthetics," Geopolitics 20(1), pp. 4-13. http://doi.org/ddj3
Derluyn, I. et al. (2014) "'We are all the same, coz exist only one earth, why the border exist': Messages of migrants on their way," Journal of Refugee Studies 27(1), pp. 1-20. http://doi.org/ddnq

Dorais, L. J. (2007) "Faith, hope and identity: Religion and the Vietnamese refugees," Refugee Survey Quarterly, 26(2), pp. 57-68. https://doi.org/10.1093/jrs/fes042

Ferris, F. S. (2010) "Appraisal, identity and gendered discourse in toilet graffiti: A study in transgressive semiotics." MA Thesis. University of the Western Cape.

Fieni, D. (2016) "Tagging the spectral mobility of the stateless body: Deleuze, stasis, and graffiti," Journal for Cultural Research, 20(4), pp. 350-365. http://doi. org/ddj4

Frederick, U. K. (2009) "Revolution is the new black: Graffiti/Art and mark-making practices," Archaeologies 5(2), pp. 210-237. http://doi.org/brgwp7

Giannakopoulos, G. (2016) "Depicting the pain of others: Photographic representations of refugees in the Aegean Shores," Journal of Greek Media \& Culture 2(1), pp. 103-114. http://doi.org/ddj5

Giannuli, D. (1995) “Greeks or 'strangers at home': The experiences of Ottoman Greek refugees during their exodus to Greece, 1922-1923', Journal of Modern Greek Studies 13(2), pp. 271-287. https://doi.org/10.1353/ mgs.2010.0196

Gielis, R. and van Houtum, H. (2012) "Sloterdijk in the house! Dwelling in the borderscape of Germany and The Netherlands," Geopolitics 17(4), pp. 797-817. http://doi.org/ddj6

Giles, K. and Giles, M. (2010) "Signs of the times: Nineteenth-twentieth century graffiti in the farms of the Yorkshire Wolds", in Wild signs: Graffiti in archaeology and history. Studies in contemporary and historical archaeology. Oxford: Archaeopress and John and Erica Hedges Ltd, pp. 47-59.

Gonos, G., Mulkern, V. and Poushinsky, N. (1976) "Anonymous expression: A structural view of graffiti," The Journal of American Folklore 89(351), pp. 40-48. http://doi.org/fftmqv

Gozdziak, E. M. and Shandy, D. J. (2002) "Editorial introduction: Religion and spirituality in forced migration," Journal of Refugee Studies 15(2), pp. 129-135. https:// doi.org/10.1093/jrs/15.2.129

Hagan, J. and Ebaugh, H. R. (2003) "Calling upon the sacred: Migrants' use of religion in the migration process," The International Migration Review 37(4), pp. 1145-1162. http://doi.org/btk7gk

Hennink, M. M. (2008) "Language and communication in cross-cultural qualitative research," in Liamputtong, $\mathrm{P}$. (ed.) Doing cross-cultural research: Ethical and methodological perspectives. Dordrecht: Springer, pp. 21-33.

Hirschon, R. (2007) "Geography, culture areas and the refugee experience. The paradoxical case of Lesvos," in Kitromilides, P. M. and Michailaris, P. D. (eds) Mytilene and Ayvalik. A bilateral historical relationship in the North-Eastern Aegean. Athens: Institute for Neohellenic Research, pp. 171-183.

Human Rights Watch (2016) Greece: Refugee 'hotspots' unsafe, unsanitary. Available at: https://www.hrw. org/news/2016/05/19/greece-refugee-hotspots-unsafe-unsanitary (Accessed: 1 May 2019). 
Borders in Globalization Review | Volume 1 | Issue 1 | Fall 2019

Wagner Tsoni \& Franck, "Writings on the Wall: Textual Traces of Transit in the Aegean "Borderscape"

IOM (2015) Mixed migration flows in the Mediterranean and beyond: Compilation of available data and information. Reporting period: 2015. Available at: https://reliefweb. int/sites/reliefweb.int/files/resources/Flows\%20 Compilation\%202015\%200verview.pdf (Accessed: 1 May 2019).

IOM (2016) Mixed migration flows in the Mediterranean and beyond: Compilation of available data and information. Reporting period: 2016. Available at: https://reliefweb. int/sites/reliefweb.int/files/resources/2016_Flows_to_ Europe_Overview.pdf (Accessed: 1 May 2019).

Jones, R. (2016) Violent borders: Refugees and the right to move. London: Verso.

Karathanasis, P. and Kapsali, K. (2018) "Displacement and the creation of emplaced activism: Public interventions on the walls of a European border city," Entanglements 1(2), pp. 52-61.

Kasparek, B. and Speer, M. (2013) "At the nexus of academia and activism: bordermonitoring.eu," Postcolonial Studies 16(3), pp. 259-268. http://doi.org/ddj7

Klingman, A., Shalev, R. and Pearlman, A. (2000) "Graffiti: A creative means of youth coping with collective trauma," The Arts in Psychotherapy 27(5), pp. 299-307. http://doi.org/d29hzp

Lachmann, R. (1988) "Graffiti as career and ideology," American Journal of Sociology 94(2), pp. 229-250. http://www.jstor.org/stable/2780774

Laszczkowski, M. and Reeves, M. (2015) "Affective states: Entanglements, suspensions, suspicions," Social Analysis 59(4), pp. 1-14. http://doi.org/ddj8

Leong, P. (2016) "American Graffiti: Deconstructing gendered communication patterns in bathroom stalls," Gender, Place \& Culture 23(3), pp. 306-327. http://doi. org/ddj9

Lucca, N. and Pacheco, A. M. (1986) "Children's graffiti: Visual communication from a developmental perspective," The Journal of Genetic Psychology 147(4), pp. 465-479. http://doi.org/cwa9fw

Madsen, K. D. (2015) "Graffiti, art, and advertising: Re-scaling claims to space at the edges of the nation-state," Geopolitics 20(1), pp. 95-120. http://doi.org/ddkb

Mignolo, W. D. (1995) The darker side of the renaissance. Literacy, territoriality \& colonization. Ann Arbor: The University of Michigan Press.

Moreau, T. and Alderman, D. H. (2011) "Graffiti hurts and the eradication of alternative landscape expression," The Geographical Review 101(1), pp. 106-124. http://doi. org/fpf2cn

Morfis, T. (2015) The first ever video from inside Amygdaleza, Popaganda. Available at: http://popaganda. gr/apoklistiko-protovinteo-pou-vgeni-pote-mesa-apotin-amigdaleza/ (Accessed: 1 May 2019).

Myrivili, E. (2009) "Transformations of political divides: Commerce, culture and sympathy crossing the GreekTurkish border," in Anastasakis, O., Nicolaïdis, K., and Öktem, K. (eds) In the long shadow of Europe: Greeks and Turks in the era of postnationalism. Leiden: Martinus Nijhoff Publishers, pp. 331-357.

Navaro-Yashin, Y. (2012) The Make-believe Space: Affective geography in a postwar polity. Durham: Duke University Press.
Noussia, A. and Lyons, M. (2009) "Inhabiting spaces of liminality: Migrants in Omonia, Athens," Journal of Ethnic and Migration Studies 35(4), pp. 601-624. http://doi.org/ fhprpn

Otta, E. et al. (1996) "Musa latrinalis: Gender differences in restroom graffiti," Psychological Reports 78, pp. 871-880. http://doi.org/dr4wtj

Papataxiarchis, E. (2016) "Being 'there'. At the front line of the 'European refugee crisis' - part 1," Anthropology Today 32(2), pp. 5-9. http://doi.org/ddkc

Papoutsi, A. et al. (2018) "The EC hotspot approach in Greece: Creating liminal EU territory," Journal of Ethnic and Migration Studies $\mathrm{O}(\mathrm{O})$, pp. 1-13. http://doi.org/ ddkd

Parker, N. and Vaughan-Williams, N. (2012) "Critical border studies: Broadening and deepening the "lines in the sand" agenda'," Geopolitics 17(4), pp. 727-733. http:// doi.org/ddkf

Perera, S. (2007) "A Pacific zone? (In)security, sovereignty, and stories of the pacific borderscape," in Borderscapes: Hidden geographies and politics at territory's edge. Minneapolis: University of Minnesota Press, pp. 201-227.

Philipps, A. (2015) "Defining visual street art: In contrast to political stencils," Visual Anthropology 28(1), pp. 51-66. http://doi.org/ddkg

Rajaram, P. K. and Grundy-Warr, C. (eds) (2007a) Borderscapes: Hidden geographies and politics at territory's edge. Minneapolis: University of Minnesota Press.

Rajaram, P. K. and Grundy-Warr, C. (eds) (2007b) Borderscapes: Hidden geographies and politics at territory's edge - Book Review. Minneapolis: University of Minnesota Press.

Rontos, K., Nagopoulos, N. and Panagos, N. (2019) The refugee and immigration phenomenon in Lesvos (Greece) and the attitudes of the local community. Newcastle upon Tyne: Cambridge Scholars Publishing.

Reeves, M. (2011) "Fixing the border: On the affective life of the state in southern Kyrgyzstan," Environment and Planning D: Society and Space 29(5), pp. 905-923. http://doi.org/cp5sv2

Rozakou, K. (2017a) "Nonrecording the 'European refugee crisis' in Greece. Navigating through irregular bureaucracy," Focaal - Journal of Global and Historical Anthropology 77, pp. 36-49. http://doi.org/ddkh

Rozakou, K. (2017b) Solidarity \#Humanitarianism: The blurred boundaries of humanitarianism in Greece, Allegra Lab. Available at: http://allegralaboratory.net/ solidarity-humanitarianism/ (Accessed: 1 May 2019).

Rumford, C. (2012) "Towards a multiperspectival study of borders," Geopolitics 17(4), pp. 887-902. http://doi.org/ddkj

Sohn, C. (2016) "Navigating borders' multiplicity: The critical potential of assemblage," Area 48(2), pp. 183-189. http://doi.org/f83hjm

Soto, G. (2016) "Place-making in non-places: Migrant graffiti in rural highway box culverts," Journal of Contemporary Archaeology 3(2), pp. 174-195. http:// doi.org/gf6sn5

Stocker, T. L. et al. (1972) "Social analysis of graffiti," Journal of American Folklore 85(338), pp. 356-366. https://www.jstor.org/stable/539324 
Symbiosis Lesvos (2016) Symbiosis Lesvos Art Festival: Photos. Available at: https://www.facebook.com/ pg/symbiosislesvos/photos/?ref=page_internal (Accessed: 1 May 2019).

Temple, B. and Edwards, R. (2002) "Interpreters/translators and cross-language research: Reflexivity and border crossings," International Journal of Qualitative Methods 1(2), pp. 1-12. http://doi.org/gcdtmj

Temple, B. and Young, A. (2004) "Qualitative research and translation dilemmas," Qualitative Research 4(2), pp. 161-178. http://doi.org/bb635w

Tsilimpounidi, M. (2015) "'If these walls could talk': Street art and urban belonging in the Athens of crisis," Laboratorium $7(2)$, pp. 18-35.

Tsilimpounidi, M. and Walsh, A. (2010) "Painting human rights: Mapping street art in Athens," Journal of Arts and Communities 2(2), pp. 111-122. http://doi.org/ b6bvj5

Tsimouris, G. (2001) 'Reconstructing 'home' among the 'enemy': The Greeks of Gökseada (Imvros) after Lausanne." Balkanologie. Revue d'études pluridisciplinaires 5(1-2), pp. 1-14.
Twinn, S. (1997) "An exploratory study examining the influence of translation on the validity and the reliability of qualitative data in nursing research," Journal of Advanced Nursing 26(2), pp. 418-423. http://doi.org/dt4fvb

UNHCR (2009) UNHCR alarmed by detention of unaccompanied children in Lesvos, Greece. Available at: http:// www.unhcr.org/news/briefing/2009/8/4a97cb719/ unhcr-alarmed-detention-unaccompanied-children-lesvos-greece.html (Accessed: 1 May 2019).

UNHCR (2016a) Daily estimates - Arrivals per location (01 Jan 2016 - 23 August 2016). Available at: https://data2. unhcr.org/en/documents/download/50765 (Accessed: 1 May 2019).

UNHCR (2016b) Daily estimates - Arrivals per location (19 Nov 2015 - 01 Apr 2016). Available at: https://data2. unhcr.org/en/documents/download/35485 (Accessed: 1 May 2019).

Wikisource.org (2017) Never regret the treachery of time. Available at: https://tinyurl.com/y2vdxrln (Accessed: 1 May 2019).

Yogan, L. J. and Johnson, L. M. (2006) "Gender differences in jail art and graffiti," The South Shore Journal 1, pp. 31-52. 